\title{
Zika Virus-Associated Aseptic Meningitis and Guillain-Barre Syndrome in a Traveler Returning from Latin America: a Case Report and Mini-Review
}

\author{
Julie Korol Wright ${ }^{1}$ - Lucas Castellani ${ }^{2}$ - Christian Lecce ${ }^{3}$ - Aisha Khatib ${ }^{3}$ - Mark Bonta ${ }^{1}$ - Andrea K. Boggild ${ }^{13,4}$
}

Published online: 15 February 2019

(C) Springer Science+Business Media, LLC, part of Springer Nature 2019

\begin{abstract}
ZIKV-associated Guillain-Barré syndrome presents with an accelerated clinical course compared to classic post-infectious Guillain-Barré syndrome. Clinicians should anticipate and screen patients with ZIKV infection for neurologic complications bearing in mind that these may manifest during the acute viremic phase or during early convalescence.
\end{abstract}

Keywords Emerging infectious diseases · Flaviviruses · Guillain-Barre syndrome · Vector-borne infections · Zika virus

\section{Introduction/Clinical Case}

A 34-year-old Canadian-born woman traveled to Nicaragua for tourism in August 2016. On the tenth day of travel, she developed a papular rash across her chest that spread along her arms, legs, and face. She became febrile and complained of muscle fatigue and weakness involving her arms and legs, arthralgia of the wrists and ankles, and global headache with photophobia. Exposures during the trip were notable for several daytime mosquito bites. She had no prior travel history and had not received prior immunization against yellow fever. She was assessed by a physician in Nicaragua who made a presumptive diagnosis of Zika virus (ZIKV) infection but no diagnostic investigations were performed.

This article is part of the Topical Collection on Tropical, Travel and Emerging Infections

Andrea K. Boggild

andrea.boggild@utoronto.ca

Julie Korol Wright

julie.wright@mail.utoronto.ca

Lucas Castellani

lucas.castellani@mail.utoronto.ca

Christian Lecce

clecce@uwo.ca

Aisha Khatib

khatib.aisha@gmail.com
She returned home 4 days after the onset of symptoms and was assessed in our unit the following day. On physical examination, the patient was afebrile with normal vital signs, with a macular rash on the lower extremities, and tender non-effusive joints in the hands, wrists, elbows, and feet. Neurologic examination identified global weakness, most pronounced in the left hip flexor (4/5). Deep tendon reflexes were normal $(2+)$ throughout. Sensation was intact but reduced in the left lower extremity. Routine blood work was normal with negative malaria testing. Serologies for travel-related infections were ordered (Table 1) and the patient was discharged home with instructions to rest and return before her 1-week follow-up should any symptoms worsen.

Mark Bonta

mark.bonta@uhn.ca

1 Department of Medicine, University of Toronto, Toronto, Canada

2 Department of Medicine, Division of Clinical Sciences, Northern Ontario School of Medicine, Sudbury, Canada

3 Tropical Disease Unit, Toronto General Hospital, 200 Elizabeth Street, Toronto 13EN-218, Canada

4 Public Health Ontario Laboratories, Toronto, Canada 
Table 1 Summary of Investigations

\begin{tabular}{|c|c|}
\hline Parameter & Result \\
\hline Hemoglobin (g/L) & 146 \\
\hline $\mathrm{WBC}\left(\times 10^{\wedge} 9 / \mathrm{L}\right)$ & 6.9 \\
\hline Platelets $\left(\times 10^{\wedge} 6 / \mathrm{L}\right)$ & 228 \\
\hline Serum creatinine $(\mu \mathrm{mol} / \mathrm{L})$ & 74 \\
\hline Serum glucose & 4.6 \\
\hline AST (U/L), ALT (U/L), ALP (U/L) & $45,54,47$ \\
\hline Total bilirubin $(\mu \mathrm{mol} / \mathrm{L})$ & 7 \\
\hline Beta HCG & Negative \\
\hline \multicolumn{2}{|l|}{ CSF } \\
\hline $\mathrm{WBC}\left(\times 10^{\wedge} 6 / \mathrm{L}\right)$ & 28 (83\% lymphocytes) \\
\hline Protein $(\mathrm{g} / \mathrm{L})$ & 0.49 \\
\hline Glucose $(\mu \mathrm{mol} / \mathrm{L})$ & 3.3 \\
\hline HSV (PCR) & Negative \\
\hline VZV (PCR) & Negative \\
\hline WNV & Negative \\
\hline ZIKV (PCR) & Detected \\
\hline \multicolumn{2}{|l|}{ Serum virus detection } \\
\hline ZIKV (PCR) & Not detected \\
\hline Dengue virus (PCR) & Not detected \\
\hline Chikungunya virus (PCR) & Not detected \\
\hline \multicolumn{2}{|l|}{ Serology } \\
\hline Zika virus & $\begin{array}{l}\text { IgM positive ZIKV PRNT > 1:160 } \\
\text { Dengue PRNT Negative }\end{array}$ \\
\hline Dengue virus & IgM + IgG Non-reactive \\
\hline Chikungunya virus & IgM + IgG Non-reactive \\
\hline West Nile virus & IgM + IgG Non-reactive \\
\hline Epstein-Barr virus & $\begin{array}{l}\text { EBNA IgG negative; } \\
\text { EBV VCA IgG positive }\end{array}$ \\
\hline Cytomegalovirus & IgG non-reactive \\
\hline Human immunodeficiency virus & Non-reactive \\
\hline
\end{tabular}

Four days later, she re-presented to our institution with headache, debilitating muscle weakness, and an inability to ambulate independently. On examination, she was afebrile and without rash. Neurologic examination revealed worsening lower extremity muscle weakness in the left hip flexor (3/5) and diminished power (4/5) in the rest of upper and lower extremity muscle groups. Deep tendon reflexes were diminished (1+) and symmetric in the upper and lower extremities. Sensory examination demonstrated decreased light touch, pain, and temperature sensation in a 'glove-and-stocking' distribution. Cranial nerve examination revealed decreased sensation (soft touch, pain, and temperature) in the left-sided distributions of cranial nerve V (V1,V2, and V3) and decreased power in the left orbicularis oculi.

Routine investigations were normal (Table 1). Magnetic resonance imaging (MRI) of the brain and spine were normal. Cerebrospinal fluid (CSF) analysis was notable for a white blood cell count of $28 / \mathrm{mm}^{3}$ ( $85 \%$ lymphocytes, reactive) and protein concentration above the upper limit of normal $(0.49 \mathrm{~g} / \mathrm{L})$. ZIKV RNA was detected from CSF via polymerase chain reaction (PCR). Serum PCR for ZIKV was negative but ZIKV IgM antibody was reactive, with plaque reduction neutralization test (PRNT) titers corroborating the molecular ZIKV diagnosis (Table 1).

The patient received supportive care in hospital over a 5day admission. She did not receive intravenous immunoglobulin (IVIG). On discharge, she was able to ambulate with the assistance of a walker and continued to report headache, fatigue, weakness, and numbness in the left thigh. She was followed in the outpatient physiatry clinic for rehabilitation support and management of the post-infectious fatigue syndrome. She was prescribed gabapentin and celecoxib for the management of chronic neuropathic pain. After 1 month, she was able to return to work on a modified schedule required to accommodate the on-going muscle fatigue and weakness. At 4 months post-discharge, she was ambulating independently. Six months post-discharge, there was residual left hip flexor weakness (4/5), decreased light touch sensation in the left lower extremity, and on-going paresthesia with chronic neuropathic pain. Nerve conduction studies performed at that time were normal. By 2 years post-discharge, all symptoms and signs had resolved.

\section{Methods}

Mini-Review We performed a non-systematic mini-review of the English language literature using the PubMed database from inception to October 26, 2018, and combinations of the search terms "Zika*", "neurologic*", and "Guillain-Barre syndrome" in order to contextualize the demographic, clinical, and laboratory features of our patient with what is already known about the Guillain-Barre syndrome in ZIKV infection. Bibliographies of literature identified by our search strategy were also hand searched for additional relevant reports. We restricted our review to studies reporting primary data on clinical course, diagnosis, and treatment of Guillain-Barre syndrome in Zika and included all observational studies, case series, and case reports.

\section{Discussion}

\section{Neurologic Sequelae of Zika Virus Infection}

Most people infected with ZIKV suffer mild, if any, symptoms typically consisting of fever, rash, arthralgia, and non-purulent conjunctivitis [1]. The putative association with neurologic disorders was first made in the 2015 ZIKV outbreak in French Polynesia with a study which found that all of the 
patients diagnosed with Guillain-Barré syndrome during the surveillance period had evidence of ZIKV infection $[2 \cdot 3]$. Since then, several case reports/series and surveillance reports from Latin American, South America, and Oceania have corroborated the association between ZIKV and Guillain-Barré syndrome $[4,5 \bullet, 6-8,9 \bullet \bullet, 10-14,15 \bullet \bullet, 16-23]$. Zika virus infection has been associated with additional neurologic complications including sensory polyneuropathy, facial paralysis, vestibulitis, encephalitis/meningoencephalitis, myelitis, and a severe congenital ZIKV syndrome characterized by fetal/ neonatal microcephaly and other central nervous system (CNS) abnormalities (reviewed in [24••, 25, 26].

\section{The Guillain-Barré Syndrome}

The Guillain-Barré syndrome is classically described as an immune-mediated, post-infectious acute polyradiculoneuropathy attributed to molecular mimicry between the antigenic epitopes of the inciting pathogen and 'self' neuronal proteins [27]. It is a known complication of many bacterial and viral infections including Campylobacter jejunii, Mycoplasma pneumoniae, Haemophilus influenzae, influenza virus, Epstein-Barr virus, cytomegalovirus, human immunodeficiency virus, and rarely the arboviruses dengue virus, chikungunya virus, and West Nile virus [27-29].

The Guillain-Barré syndrome features progressive, symmetric muscle weakness and diminished or absent deep tendon reflexes, but a spectrum of neurologic manifestations including facial muscle weakness and paresthesia of the hands and feet is well described. Symptoms typically evolve over 2 to 4 weeks following a period of latency after an acute infection or vaccination. Cerebrospinal fluid findings include elevated protein concentration with a white blood cell count $<50$ / $\mathrm{mm}^{3}$ (the albuminocytologic dissociation), while nerve conduction studies (NCS) are useful in identifying specific disease variants.

\section{Zika Virus-Associated Guillain-Barré Syndrome}

The patient presented in the clinical vignette had many features consistent with the Guillain-Barré syndrome though the relatively short interval between the onset of ZIKV illness and neurologic symptoms, and the rapid progression to symptomatic nadir, are atypical of classic post-infectious Guillain-Barré syndrome. Emerging reports of Guillain-Barré-like syndromes from ZIKVaffected regions have described similar clinical profiles (Table 2). A case series conducted in Colombia found that almost half of the patients with proven ZIKV infection and Guillain-Barré syndrome manifested neurologic symptoms soon after onset of the viral illness; $40 \%$ had concurrent viremia at the time of their admission for management of the Guillain-Barré syndrome and $57 \%$ had positive ZIKV studies from CSF [5••]. These findings have led to speculation that neurologic sequelae of ZIKV infection may result from direct viral infection of peripheral nerves (reviewed in [30••]. Zika virus is phylogenetically related to other neurotropic flaviviruses such as West Nile virus and Japanese encephalitis virus, and the neurotropism of ZIKV has been well established in murine models [31]. However, while studies of human tissues are limited, a recent report of a sural nerve biopsy taken from a patient with ZIKV and Guillain-Barré syndrome did not detect ZIKV in nerve tissue [32, 33]. Alternatively, there is evidence of considerable peptide overlap between the ZIKV polyprotein and human neural proteins [34]. The ZIKV incubation period may provide the time required to generate crossreactive antibodies, thus allowing concurrent manifestation of ZIKV and neurologic symptoms. Serum analyses have confirmed the presence of circulating autoantibodies in patients with ZIKV-associated Guillain-Barré syndrome, but the anti-ganglioside antibodies typically associated with the Guillain-Barré syndrome are rarely apparent [2•]. These observations raise the possibility that a novel host target is implicated ZIKV-induced Guillain-Barré syndrome [33].

The spectrum of clinical severity associated with Guillain-Barré-like syndrome following ZIKV infection is broad. Case series have reported rates of admission to intensive care units ranging from 38 to $69 \%$ and the need for assisted ventilation ranging from 29 to $35 \%[2 \cdot, 6,7$, $9 \bullet \bullet]$. The majority of the patients reported in the literature received IVIG at the time of diagnosis; however, there have been no prospective or randomized clinical trials to evaluate the efficacy of this intervention or other modalities used in the management of classic Guillain-Barré syndrome, such as plasma exchange (PLEX), for the management of ZIKV-associated neurologic complications (Table 2). Nevertheless, the World Health Organization now recommends either IVIG or PLEX therapy for all patients with Guillain-Barré syndrome who have rapidly progressive symptoms, are unable to walk unaided, or who develop progressive bulbar weakness [35].

While patients reach the nadir of neurologic symptoms within a few days of onset, resolution requires a protracted period of recovery in keeping with the time required for repair of demyelinated peripheral nerves. Anaya and colleagues describe 29 patients with confirmed/probable ZIKV infection complicated by Guillain-Barré syndrome, over half of whom were bed- or chair-bound at the time of discharge [6]. Dirlikov and colleagues reported that $45 \%$ of patients in their cohort were discharged from hospital to a rehabilitation facility or a skilled nursing facility [23]. Among the cases reviewed in Table 2, most patients 


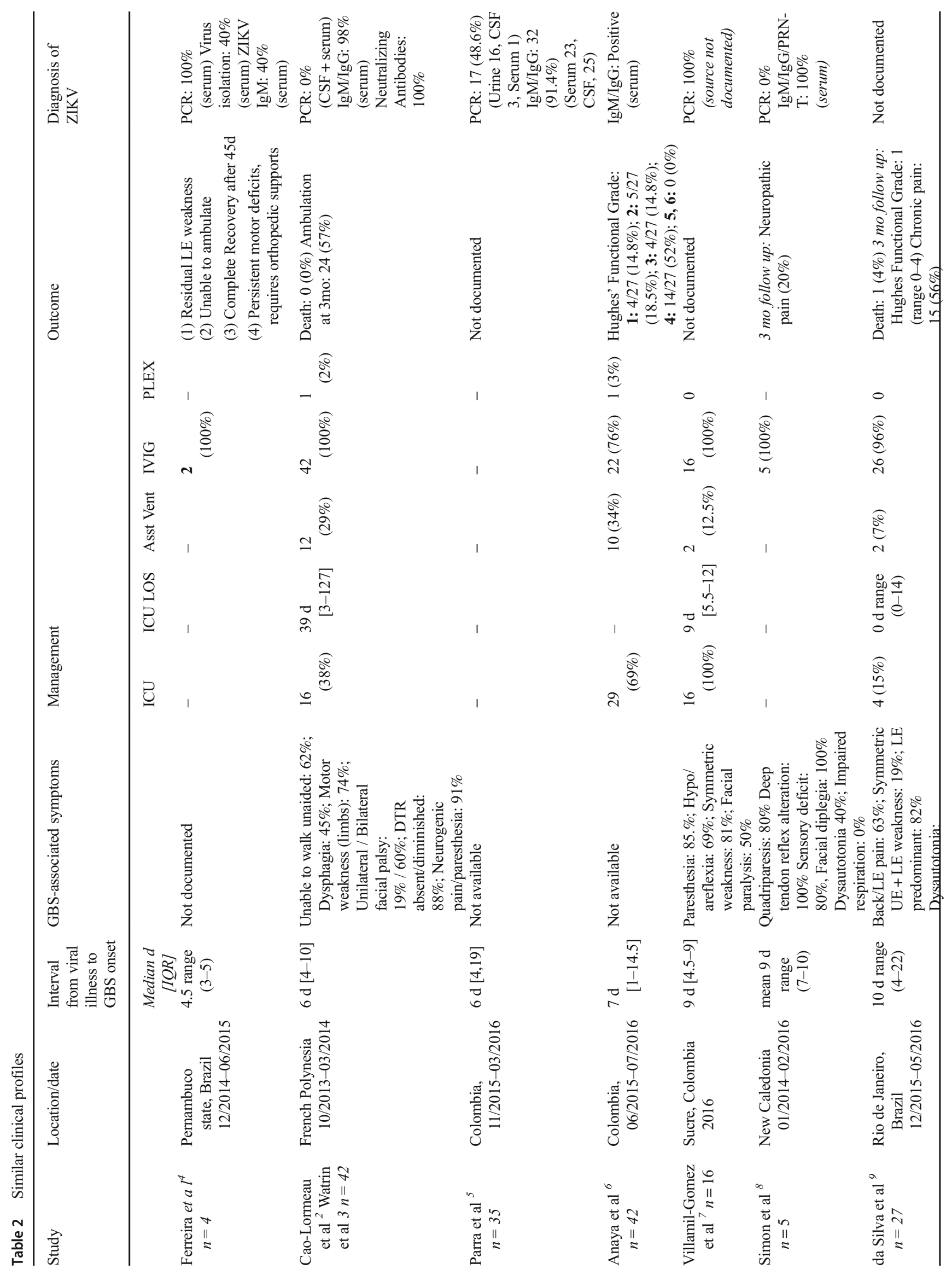




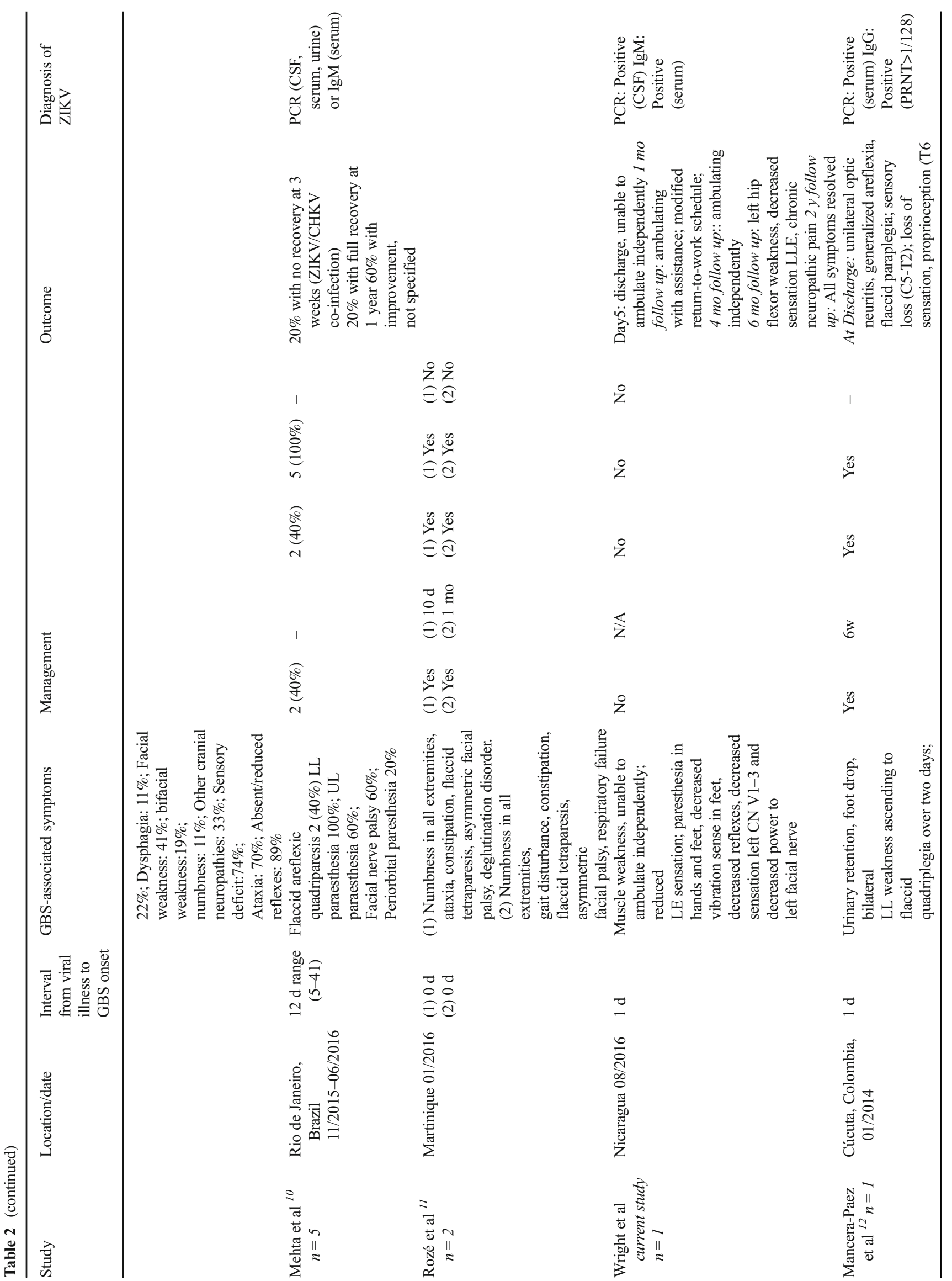




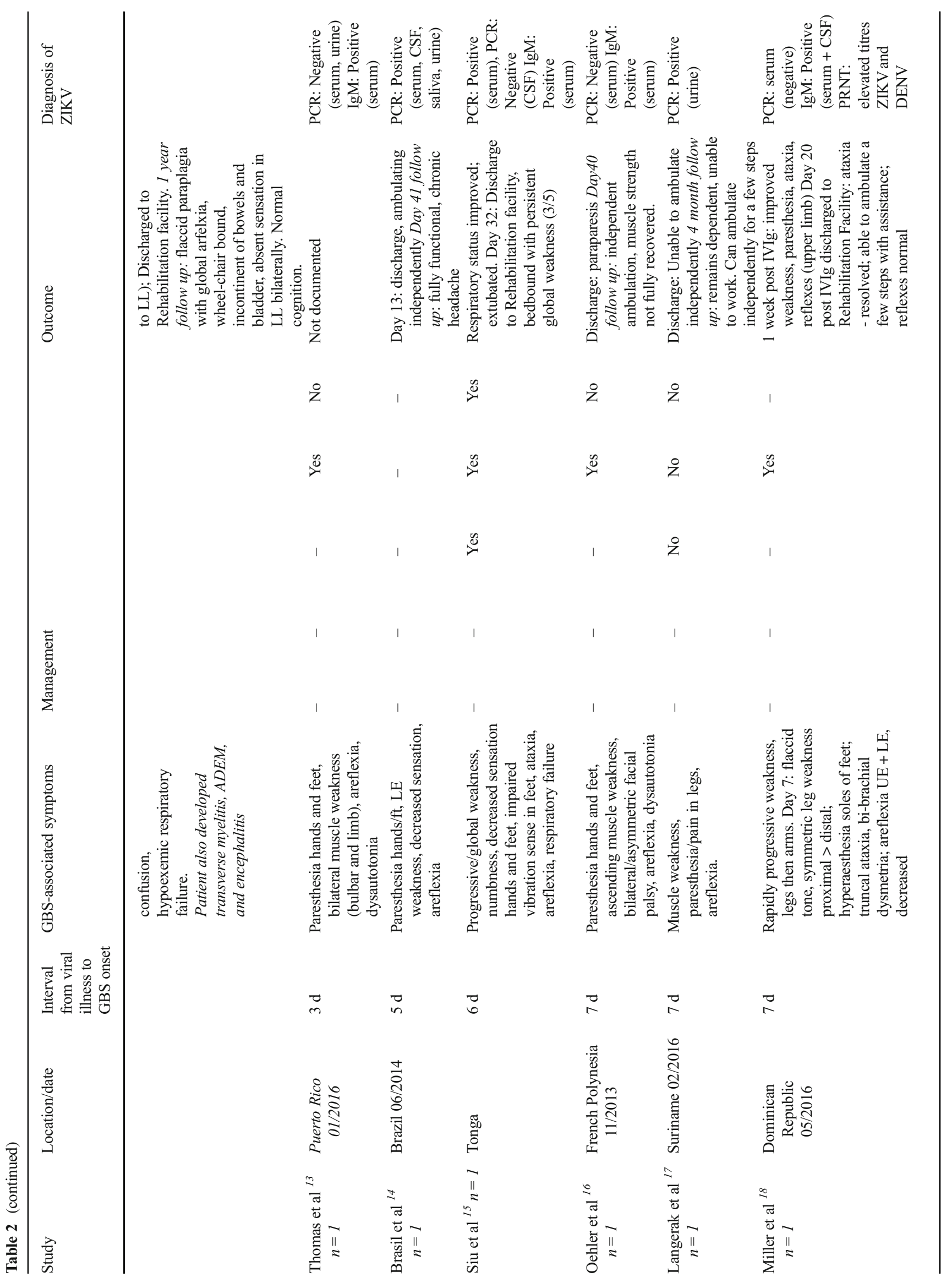




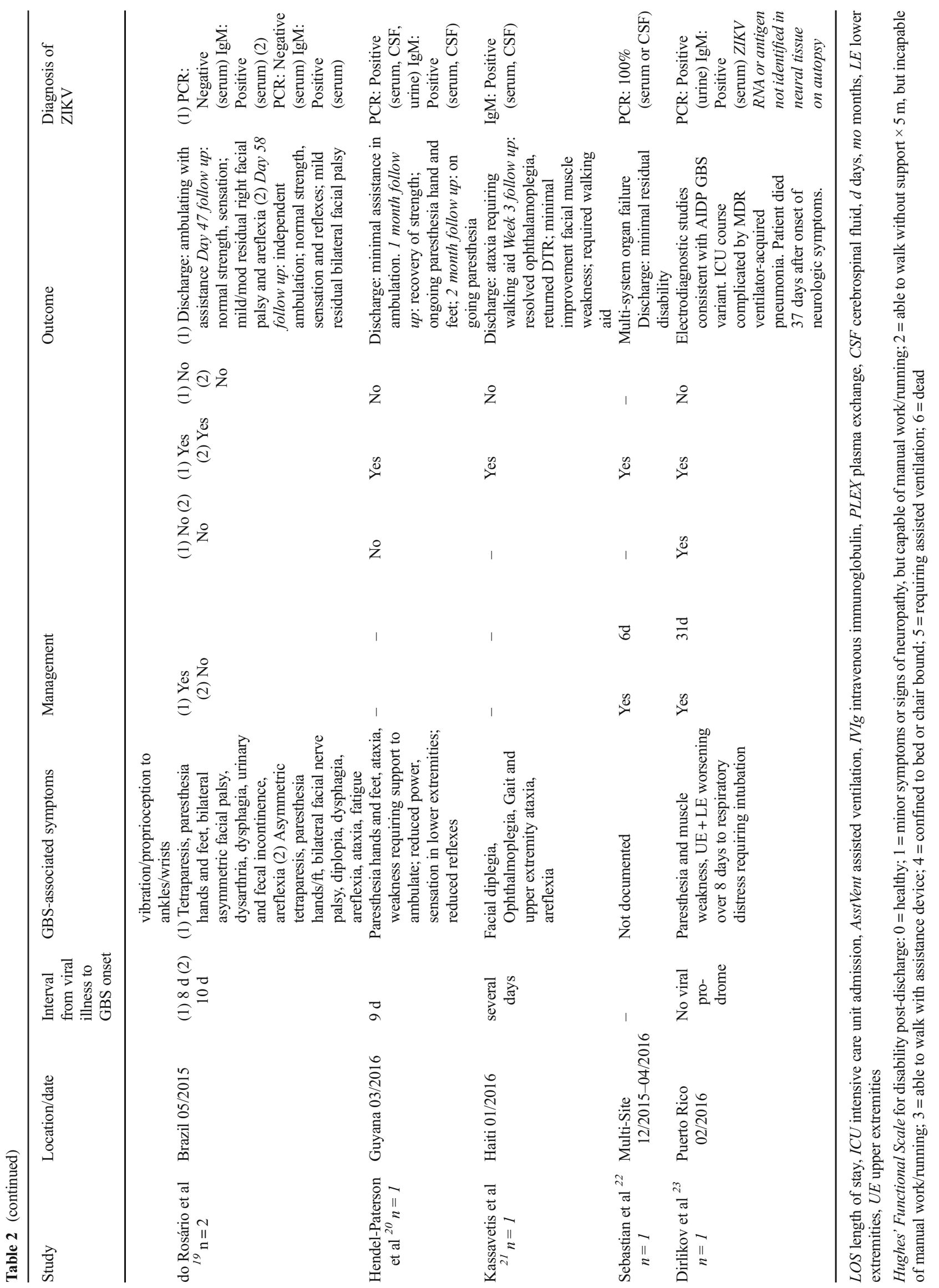


with Guillain-Barré syndrome regained independent ambulation several weeks following infection. Neuropathic pain and paresthesia can take longer to resolve.

\section{Conclusions}

There has been an exponential rise in the number of reported ZIKV infections among travelers since 2013 [36••, 37-40]. A wide spectrum of acute ZIKV infection manifestations have been reported in Canadian travelers returning from South America and the Caribbean, including neurologic complications. Currently, the pathogenesis of ZIKV-associated Guillain-Barré syndrome is poorly understood. It may involve the classic mechanisms of immune-mediated polyradiculoneuropathy, or result from direct cytopathic effect of ZIKV infection, or both.

Returned travelers from ZIKV-endemic regions with onset of the Guillain-Barré-like syndrome warrant testing for markers of ZIKV infection, including PCR (serum, urine, $\mathrm{CSF}$ ) and $\operatorname{IgM} / \operatorname{IgG}$ serology (serum, CSF), and should be followed carefully until the nadir of the neurologic symptoms is established and the symptoms of active viremia have abated. Progressive neurologic compromise may necessitate monitoring and treatment in an intensive care unit. Zika virusassociated Guillain-Barré syndrome can result in long-term disability. Patients should be counseled to expect a protracted recovery period and may benefit from multidisciplinary rehabilitation therapy as well as pharmacologic therapy to manage neuropathic pain.

Authors' Contributions JKW contributed to literature review, data collection, analysis, and interpretation, and was primarily responsible for drafting the manuscript. LC contributed to literature review, data collection, analysis, and interpretation, and to critical appraisal of the manuscript. CL and AK contributed to literature review, data collection, and data analysis. MB contributed to data collection, data analysis, and to critical appraisal of the manuscript. AKB conceived the report and contributed to literature review, data analysis and interpretation, and to writing and revising the text.

\section{Compliance with Ethical Standards}

Conflict of Interest All authors declare that they have no conflict of interest.

Human and Animal Rights and Informed Consent This article does not contain any studies with human or animal subjects performed by any of the authors.

Disclosures AKB serves on the Committee to Advise on Tropical Medicine and Travel (CATMAT), an external advisory body to the Public Health Agency of Canada.

Ethics Statement The patient described herein provided full informed consent for the report.
Publisher's Note Springer Nature remains neutral with regard to jurisdictional claims in published maps and institutional affiliations.

\section{References}

Papers of particular interest, published recently, have been highlighted as:

- Of importance

•• Of major importance

1. Huits R, Maniewski U, Van Den Bossche D, Lotgering E, Tsoumanis A, Cnops L, et al. A cross-sectional analysis of Zika virus infection in symptomatic and asymptomatic non-pregnant travellers: experience of a European reference center during the outbreak in the Americas. Travel Med Infect Dis 2018.

2. Cao-Lormeau V-M, Blake A, Mons S, Lastère S, Roche C, Vanhomwegen J, et al. Guillain-Barré Syndrome outbreak associated with Zika virus infection in French Polynesia: a case-control study. Lancet. 2016;387(10027):1531-9 This case-control study strongly supported the association between Guillain-Barre syndrome and Zika virus infection outside of the Americas.

3. Watrin L, Ghawché F, Larre P, Neau J-P, Mathis S, Fournier E. Guillain-Barré syndrome (42 cases) occurring during a Zika virus outbreak in French Polynesia. Medicine. 2016;95(14):e3257.

4. Brito Ferreira ML, Antunes de Brito CA, Moreira ÁJP, de Morais Machado MÍ, Henriques-Souza A, Cordeiro MT, et al. GuillainBarré syndrome, acute disseminated encephalomyelitis and encephalitis associated with Zika virus infection in Brazil: detection of viral RNA and isolation of virus during late infection. Am J Trop Med Hyg. 2017;97(5):1405-9.

5.•P Parra B, Lizarazo J, Jiménez-Arango JA, Zea-Vera AF, GonzálezManrique G, Vargas J, et al. Guillain-Barré Syndrome Associated with Zika Virus Infection in Colombia. N Engl J Med. 2016;375(16):1513-23 This observational series strongly supported the association between Guillain-Barre syndrome and Zika virus infection during a period of intense transmission of ZIKV in Colombia.

6. Anaya J-M, Rodríguez Y, Monsalve DM, Vega D, Ojeda E, González-Bravo D, et al. A comprehensive analysis and immunobiology of autoimmune neurological syndromes during the Zika virus outbreak in Cúcuta, Colombia. J Autoimmun. 2017:77:123-38.

7. Villamil-Gomez WE, Sánchez-Herrera ÁR, Hernandez H, Hernández-Iriarte J, Díaz-Ricardo K, Castellanos J, et al. Guillain-Barre syndrome during the Zika virus outbreak in Sucre, Colombia, 2016. Travel Med Infect Dis. 2017;16:62-3.

8. Simon O, Acket B, Forfait C, Girault D, Gourinat A-C, Millon P, et al. Zika virus outbreak in New Caledonia and Guillain-Barré syndrome: a case-control study. J Neuro-Oncol. 2018;24(3):362-8.

9.• da Silva IRF, Frontera JA, Bispo de Filippis AM, Nascimento OJMD, for the RIO-GBS-ZIKV Research Group. Neurologic Complications Associated With the Zika Virus in Brazilian Adults. JAMA Neurol. 2017;74(10):1190-9 This cohort study documented the range of severe neurologic sequelae of Zika virus infection during the outbreak in Brazil.

10. Mehta R, Soares CN, Medialdea-Carrera R, Ellul M, da Silva MTT, Rosala-Hallas A, et al. The spectrum of neurological disease associated with Zika and chikungunya viruses in adults in Rio de Janeiro, Brazil: A case series. Beasley DWC, editor. PLOS Negl Trop Dis. 2018;12(2):e0006212.

11. Rozé B, Najioullah F, Signate A, Apetse K, Brouste Y, Gourgoudou $\mathrm{S}$, et al. Zika virus detection in cerebrospinal fluid from two patients 
with encephalopathy, Martinique, February 2016. Eur Secur. 2016;21(16):30205.

12. Mancera-Páez O, Román GC, Pardo-Turriago R, Rodríguez Y, Anaya J-M. Concurrent Guillain-Barré syndrome, transverse myelitis and encephalitis post-Zika: a case report and review of the pathogenic role of multiple arboviral immunity. J Neurol Sci. 2018 Dec;395:47-53.

13. Thomas DL, Sharp TM, Torres J, Armstrong PA, Munoz-Jordan J, Ryff KR, et al. Local transmission of Zika virus - Puerto Rico, November 23, 2015-January 28, 2016. MMWR Morb Mortal Wkly Rep. 2016;65(6):1-6 Available from: http://www.cdc.gov/ mmwr/volumes/65/wr/mm6506e2er.htm. Accessed 15 Nov 2018.

14. Brasil P, Sequeira PC, Freitas AD, Zogbi HE, Calvet GA, de Souza $\mathrm{RV}$, et al. Guillain-Barré syndrome associated with Zika virus infection. Lancet. 2016;387(10026):1482.

15.• Siu R, Bukhari W, Todd A, Gunn W, Huang QS, Timmings P. Acute Zika infection with concurrent onset of Guillain-Barré Syndrome. Neurology. 2016;87(15):1623-4 Available from: http://www.neurology.org/content/87/15/1623.full. One of the initial reports to describe Guillain-Barre syndrome as an acute complication, rather than a late post-infectious complication, of Zika virus infection.

16. Oehler E, Watrin L, Larre P, Leparc-Goffart I, Lastère S, Valour F, et al. Zika virus infection complicated by Guillain-Barré syndrome - case report, French Polynesia, December 2013. Eur Secur. 2014;19(9):20720

17. Langerak T, Yang H, Baptista M, Doornekamp L, Kerkman T, Codrington J, et al. Zika Virus Infection and Guillain-Barré Syndrome in Three Patients from Suriname. 3rd ed. Front Neurol. 2016;7(24):233.

18. Miller E, Becker Z, Shalev D, Lee CT, Cioroiu C, Thakur K. Probable Zika virus-associated Guillain-Barré syndrome: challenges with clinico-laboratory diagnosis. J Neurol Sci. 2017;375(C):367-70.

19. do Rosário MS, de Jesus PAP, Vasilakis N, Farias DS, Novaes MAC, Rodrigues SG, et al. Guillain-Barré syndrome after Zika virus infection in Brazil. Am J Trop Med Hyg. 2016;95(5):115760.

20. Hendel-Paterson B, Anderson K, Fabrizius RG, Walker PF, Maalim S, Kaiser RM. Guillain-Barré syndrome associated with Zika virus infection in a traveler returning from Guyana. Am J Trop Med Hyg. 2016;95(5):1161-5.

21. Kassavetis P, Joseph J-MB, Francois R, Perloff MD, Berkowitz AL. Zika virus-associated Guillain-Barré syndrome variant in Haiti. Neurology. 2016;87(3):336-7.

22. Sebastián UU, Ricardo AVA, Alvarez BC, Cubides A, Luna AF, Arroyo-Parejo M, et al. Zika virus-induced neurological critical illness in Latin America: severe Guillain-Barre syndrome and encephalitis. J Crit Care. 2017 Dec 1;42:275-81.

23. Dirlikov E, Major CG, Mayshack M, Medina N, Matos D, Ryff KR, et al. Guillain-Barré syndrome during ongoing Zika virus transmission - Puerto Rico, January 1-July 31, 2016. MMWR Morb Mortal Wkly Rep. 2016;65(34):910-4.

24.• Duca LM, Beckham JD, Tyler KL, Pastula DM. Zika Virus Disease and Associated Neurologic Complications. Curr Infect Dis Rep.
2017;19(1):4 A comprehensive review of the range of neurologic manifestations of Zika virus infection.

25. Chimelli L, Melo ASO, Avvad-Portari E, Wiley CA, Camacho AHS, Lopes VS, et al. The spectrum of neuropathological changes associated with congenital Zika virus infection. Acta Neuropathol. 2017 Jun;133(6):983-99.

26. Russo FB, Jungmann P, Beltrão-Braga PCB. Zika infection and the development of neurological defects. Cell Microbiol. 2017;31: 19(6).

27. Esposito S, Longo MR. Guillain-Barré syndrome. Autoimmun Rev. 2017;16(1):96-101.

28. Simon O, Billot S, Guyon D, Daures M, Descloux E, Gourinat AC, et al. Early Guillain-Barré syndrome associated with acute dengue fever. J Clin Virol. 2016;77:29-31.

29. Wielanek AC, Monredon JD, Amrani ME, Roger JC, Serveaux JP. Guillain-Barré syndrome complicating a chikungunya virus infection. Neurology. 2007;69(22):2105-7.

30.• Miner JJ, Diamond MS. Zika Virus Pathogenesis and Tissue Tropism. Cell Host Microbe. 2017;21(2):134 42 A comprehensive review of ZIKV neuropathophysiology.

31. Ramos da Silva S, Gao S-J. Zika virus update II: recent development of animal models-proofs of association with human pathogenesis. J Med Virol. 2016;88(10):1657-8.

32. Dirlikov E, Torres JV, Martines RB, Reagan-Steiner S, Pérez GV, Rivera A, et al. Postmortem findings in patient with Guillain-Barré syndrome and Zika virus infection. Emerg Infect Dis. 2018;24(1): 114-7.

33. Nascimento OJM, da Silva IRF. Guillain-Barré syndrome and Zika virus outbreaks. Curr Opin Neurol. 2017;30(5):500-7.

34. Lucchese G, Kanduc D. Zika virus and autoimmunity: from microcephaly to Guillain-Barré syndrome, and beyond. Autoimmun Rev. 2016;15(8):801-8.

35. World Health Organization. Assessment and management of Guillain-Barré syndrome in the context of Zika virus infection: Interim Guidance Report. 2016. pp. 1-10.

36.• Wilder-Smith A, Chang CR, Leong WY. Zika in travellers 19472017: a systematic review. J Travel Med. 2018;25(1):e101 A carefully constructed knowledge synthesis of the global burden of Zika virus infection in traveling populations.

37. Wang G, Zheng W, Zhu S, Wu Z, Lam TT, Tong Y, Qi R. A cluster of Zika virus infection among travellers returning to China from Samoa: a case tracing study. J Travel Med. 2018;25(1). doi: https:// doi.org/10.1093/jtm/tay022.

38. Sokal A, D'Ortenzio E, Houhou-Fidouh N, Brichler S, Dorchies J, Cabras O, Leparc-Goffart I, Yazdanpanah Y, Matheron S. Zika virus infection: report of the first imported cases in a Paris travel Centre. J Travel Med. 2016;24(1). doi: https://doi.org/10.1093/jtm/ taw066.

39. Quam MB, Wilder-Smith A. Estimated global exportations of Zika virus infections via travellers from Brazil from 2014 to 2015. J Travel Med. 2016;23(6). doi: https://doi.org/10.1093/jtm/taw059.

40. Summers DJ, Acosta RW, Acosta AM. Zika virus in an American recreational traveler. J Travel Med. 2015;22(5):338-40. 